an elaborate plan of campaign, in which the authors relegate in wholesale fashion to the State responsibility for the handling of the tuberculosis problem, the sentence seems to us misleading.

We think it right to say that the resolution which was adopted by the Conference was limited to the question of working men's invalidity insurance. The actual terms of the resolution were as follows :-

That the special attention of the Chancellor of the Exchequer, Government, and Parliament be called to the great importance of giving the prevention and treatment of tuberculosis a prominent place in the proposed scheme of invalid insurance.

We are, Sir, yours faithfully,

W. LesLiE LYALT, M.B. Joint Honorary JAMeS MILLER, M.D. $\}$ Secretaries.

Edinburgh, Jan, 17th, 1911.

\section{A POINT IN CHOLELITHIASIS.}

\section{To the Editor of THE LANCET.}

SIR,-In your issue of Dec. 24th last Dr. Duncan Macartney asks for instances where large numbers of gall-stones have been removed by operation. In February, 1910, I operated upon a male patient of Dr. W. B. Chapman of Rochdale, and removed 3007 gall-stones, varying in size from a hazel nut to a split pea, and all facetted. The stones are now in my possession, though I have not myself verified their number, the patient having counted them during his convalescence. He had suffered for many years from severe attacks of colic, each of very short duration, and on no occasion followed by jaundice. The gall-bladder appeared, apart from the presence of these calculi, to be normal, and I performed merely a cholecystostomy. His convalescence was interrupted by an attack of pulmonary embolism in the third week, followed by embolic pneumonia, from which he ultimately made a good recovery, and he is now in excellent health.

I am, Sir, yours faithfully.

Manchester, Jan. 16th, 1911.

ARTHUR H. BURGESS.

The Prince Francis of Teck Memorial Fund. -At the Memorial Concert for the late Prince Francis of Teck, to be held in aid of the funds of the Miädlesex Hospital at Queen's Hall on Jan. 24th, the programme will consist of Beethoven's overture, "Leonora III.," Verdi's famous "Requiem," with 500 voices and instruments, by the Brighton Choir and Festival Orchestra, under Mr. Joseph Sainton, and Wagner's triumphant "Heldegungs-Marsch." The soprano parts will be sung by Miss Alys Bateman, who needs no introduction. Other artists on the programme are Hannah Jones, Ben Davies, and Edmund Burke, the last-named by permission of the Italian Opera Company, Covent Garden.

Literary Intelligence. - Messrs. J. and A. Churchill announce for publication a new edition of Vol. IV. of "Allen's Commercial Organic Analysis," which has been rewritten under the editorship of Mr. W. A Davis, B.Sc., and Mr. S. S. Sadtler, S.B. The subjects and authors are as follows: Resins, by M. B. Blackler; Indiarubber, Rubber Substitutes, and Gutta-percha, by E. W. Lewis; Hydrocarbons and Ketones of Essential Oils, by T. M. Lowry; Volatile or Essential Oils, by E. J. Parry Special Characters of Essential Oils and Tables of Essential Oils, by H. Leffmann and C. H. LaWall. It will be seen that each subject is handled by an expert in his department. - Messrs. George Newnes, Limited, announce the impending publication of "Careers for Men, Women, and Children," a book describing most occupations, giving information regarding education or training required, length of time taken in preparation, the cost of qualifying, incomes to be made, and prospects afforded by the employments.-Messrs. W. B. Saunders Company announce that they have in the press for immediate publication a work on "The Anatomic and Histological Processes of Bright's Disease," by Dr. Horst Oertel, director of the Russell Sage Institute of Pathology, New York. In the preparation of this work the author has had in mind a twofold aim - to present the visual picture of nephritis and to prepare the proper way for the understanding of the genesis of the disease.

\section{THE HOUSING PROBLEM IN SOUTH WALES.}

(From our Spectal Sanitary Commissioner.)

Merthyr Tydfil, Dec. 1st, 1910.

The Valley of Martyrdom.

THE problem of the housing of the poor, always difficult and nowhere satisfactorily solved, has been stated to be specially acute in both North and South Wales. Undoubtedly there are in South Wales very substantial reasons why this is likely to be the case. There is the rapid and uneven growth of population of South Wales, springing from 587,000 in 1801 to $2,013,000$ in 1901. If, however, this more than threefold increase had been evenly spread over Wales it would not have mattered, but half the population of South Wales is living in Glamorganshire, which is only oneninth of the entire area. Here the augmentation of in. habitants during the last century has been fourteenfold, and no one will be surprised to find that the building of houses has not kept pace with the advent of the new inhabitants. Thus the housing trouble, urgent in all large agglomerations, is specially serious round and about the great ironworks and mining industries of South Wales. The Local Government Board, fully cognisant of the figures, caused a series of special investigations to be made, and some four years ago published many reports on the subject. The chief centre, of course, is Merthyr Tydfil, where a Christian princess named Tydfil was martyred in the sixth century. The church subsequently raised to commemorate this martyrdom has become the centre of a great manufacturing district where many thousands have been brought prematurely to the grave-martyrs to the Moloch of modern industrialism. Indeed, the Merthyr Valley, or the Valley of Martyrdom, is no misnomer, and its sinister appearance does not belie its reputation. It is black, its people are dirty, many have but miserable rags to wear, there is smoke and coal-dust and soot suspended as a pall over the whole scene, while from the centre terrible volcanic eruptions constantly occur that suggest an invasion from the lower regions. It is appalling, but it is also grand, suggesting mighty powers, mastery over the forces of nature, the conquest of the earth and its treasures; but the pity of it is the accompaniment of so much human misery. Why not master the secret of human happiness? Would not this be preferable even to a Bessemer blast furnace?

\section{A Modern Inferno.}

The story goes that a traveller approaching the Dowlais district of Merthyr asked to be driven back quickly, declaring that he had never before been so near to hell. The word remains. It is no unusual thing for a person to say he has come from hell when he has been to Dowlais. The ironworks for which Dowlais is renowned are situated in a valley, and the hill overlooking them is covered by some of the worst slum dwellings. It was while visiting after dark these hovels where the wealth producers of Dowlais dwell that I was able to contemplate what has so often been compared with the infernal regions. On one side of the works there is a large stretch of open flat ground covered over with rollers that are ever revolving, so that any heavy object placed on them is pushed forward by their rotary action. Formerly these objects required much labour to move; they now glide along as if of their own accord, and the worker who used to manipulate the iron rails is thrown out of employment, his poverty accentuating the housing difficulty. From a fiery region under the Bessemer blast furnace I saw red-hot iron railway lines glide along like great incandescent serpents. Occasionally they pass under an iron structure which squeezes them into a longer and more correct shape, till finally, and as a last ordeal, a steel rotary saw chips off the irregularly shaped tip and tail of the rail. Then the fiery serpent makes a horrible hissing noise and squirts out in all directions, as if it was its life blood, a shower of red-hot iron drops. After that one more glide, and the rail has reached its resting-place, where it cools down and loses its bright redness. All this goes on automatically, not a man is to be seen, any amount of work is done, but independently of human labour, while the unemployed clamour at the gates or shiver and starve 